\title{
Oocyte growth and follicular development in KIT-deficient Fas-knockout mice
}

\author{
Mohammad Moniruzzaman, Kazuhiro Sakamaki ${ }^{1}$, Yukiko Akazawa and Takashi Miyano \\ Graduate School of Science and Technology, Kobe University, Kobe 657-8501, Japan and ${ }^{1}$ Graduate School of \\ Biostudies, Kyoto University, Kyoto 606-8507, Japan \\ Correspondence should be addressed to M Moniruzzaman; Email: 026d910n@stu.kobe-u.ac.jp
}

\begin{abstract}
In mammals, oocyte growth and follicular development are known to be regulated by KIT, a tyrosine kinase receptor. Fas is a member of the death receptor family inducing apoptosis. Here, we investigated germ cell survival, oocyte growth and follicular development in KIT-deficient $\left(\mathrm{W}^{\mathrm{v}} / \mathrm{W}^{\mathrm{v}}:\right.$ Fas $\left.^{+/+}\right)$, Fas-deficient $\left(+/+\right.$Fas $\left.^{-1-}\right)$, and both KIT- and Fas-deficient $\left(\mathrm{W}^{\mathrm{v}} / \mathrm{W}^{\mathrm{v}}:\right.$ Fas $^{-1-}$ ) mice during fetal and postnatal periods. Further, the ovaries of these mice were transplanted in immunodeficient mice to compare oocyte growth and follicular development under a condition isolated from the extraovarian effects of KIT- and Fas-deficiency.

Higher numbers of germ cells were found in the fetal and postnatal ovaries of Fas-deficient mice than in the same-aged wild-type mice. In KIT-deficient mice, ovaries at 13 days postcoitum $(\mathrm{dpc})$ contained $1106 \pm 72(n=3)$ germ cells, but the ovaries contained no oocytes after birth. Twenty-one days after transplantation of the ovaries at $13 \mathrm{dpc}$, no oocytes/germ cells were found. A higher number of germ cells $(3843 \pm 108 ; n=3)$ were observed in the $W^{\mathrm{v}} / W^{\mathrm{v}}:$ Fas ${ }^{-/-}$genotypes than in $W^{\mathrm{v}} / \mathrm{W}^{\mathrm{v}}: \mathrm{Fas}^{+/+}$mice at 13 dpc. Furthermore, $\mathrm{W}^{\mathrm{v}} / \mathrm{W}^{\mathrm{v}}:$ Fas $^{-1-}$ mice contained $528 \pm 91(n=3)$ oocytes at 2 days, and follicles developed to the antral stage at 14 days of age. After transplantation of fetal and neonatal ovaries from $W^{\mathrm{v}} / \mathrm{W}^{\mathrm{v}}:$ Fas $^{-1-}$ mice, increased numbers of growing oocytes and developing follicles were obtained compared with those in 14-day old ovaries in vivo. These results show that oocytes grow and follicles develop without KIT signaling, although KIT might be essential for the survival of germ cells/oocytes in mice. Reproduction (2007) 133 117-125
\end{abstract}

\section{Introduction}

In the fetal mouse ovary, oogonia proliferate mitotically, and some of them differentiate to oocytes by entering meiosis at 13.5 postcoitum (dpc; Guigon \& Magre 2006). Around birth, a single layer of flattened granulosa cells surrounds each oocyte (primordial oocyte) to form the primordial follicles, and then the follicles develop towards the antral stage while oocytes reach to their full size of $75 \mu \mathrm{m}$. A large number of germ cells/oocytes are known to undergo degeneration during fetal and early postnatal stages. Approximately, $65 \%$ of germ cells degenerate from $13.5 \mathrm{dpc}$ to birth (McClellan et al. 2003). After birth, a small number of primordial oocytes enter the growth phase and reach full size, although the oocyte population is continuously reduced. The cause of germ cell degeneration remains largely unknown, and rescuing these germ cells seems to be difficult (Reynaud \& Driancourt 2000, Guigon \& Magre 2006).

Several growth factors and cytokines are thought to regulate the process of germ cell/oocyte survival and follicular development (Reynaud \& Driancourt 2000, Eppig 2001). Among those KIT, a tyrosine kinase receptor and its ligand, KIT Ligand (KL, which is also known as steel factor, stem cell factor, or mast cell growth factor) are important regulators for the survival of germ cells, growth of oocytes, and folliculogenesis (Driancourt et al. 2000). mRNA for both soluble and membrane-bound forms of KL was detected in juvenile and adult mouse ovaries (Manova et al. 1993) and in granulosa cells isolated from mouse preantral follicles (Joyce et al. 1999). Expression of KIT mRNA and KIT protein has been detected in primordial, growing and fully grown oocytes (Manova et al. 1993).

KIT and $\mathrm{KL}$ are encoded at white spotting $(\mathrm{W})$ and steel (SI) loci in the mouse respectively (Geissler et al. 1988, Chabot et al. 1988, Copeland et al. 1990, Huang et al. 1990, Zsebo et al. 1990). Mutant mice for the W and SI loci show similar phenotypes such as anemia, a decreased number of mast cells, lack of pigmentation, and infertility (Russell 1979). Many alleles of variable severity at both $\mathrm{W}$ and $\mathrm{SI}$ loci have been identified (Besmer et al. 1993). Wv mutant mice with the C57BL/6 
background have a single-point mutation at 2007 (C-T) of the kit sequence, which involves the change of threonine to methionine at position 660 in the cytoplasmic region of KIT. In $\mathrm{W}^{\mathrm{V}} / \mathrm{W}^{\mathrm{V}}$ mice, oogenesis completely fails, resulting in no follicles or oocytes in the ovaries. Moreover, KIT/KL is known to play a key role in activation of primordial follicles, oocyte growth and then follicular development (Driancourt et al. 2000). It is reported that neutralizing KIT by injecting ACK2, a function-blocking antibody, causes disturbances in initial follicle recruitment in mice (Yoshida et al. 1997). Oocyte growth and follicle development stopped at the primary stage in KL mutant mice (Kuroda et al. 1988, Huang et al. 1993). Furthermore, results from in vitro studies suggest that $\mathrm{KL}$ promotes the development of primordial follicles in rodents (Parrott \& Skinner 1999). Packer et al. (1994) have reported that KIT and KL are required for oocyte growth. Inhibition of oocyte growth was obtained as a result of ACK2 treatment in vitro.

Fas is a member of death receptor family. It induces programmed cell death in various organs including testis and ovary. It is expressed in granulosa cells and oocytes during folliculogenesis, and in luteal cells (Sakamaki et al. 1997). Its expression in granulosa and luteal cells suggests that Fas is involved in follicular atresia and luteolysis. Defective KIT signaling leads to the activation of a Fas-mediated apoptotic signal in germ cells, and thus Fas is involved in germ cell loss in KIT-deficient $\mathrm{W}^{\mathrm{v}} / \mathrm{W}^{\mathrm{V}}$ mice (Sakata et al. 2003). Since the rescue of testicular germ cells as well as oocytes by Fas deficiency in KITdeficient mice has been revealed, the role of KIT in oocyte growth and follicular development has become an issue to be reconsidered.

The present study was aimed at further elucidating the involvement of KIT in the survival of female germ cells, the activation of primordial oocytes, and follicular development. We examined ovaries from $\mathrm{W}^{\mathrm{v}} / \mathrm{W}^{\mathrm{v}}$ :Fas ${ }^{+}$ ${ }^{\prime+}, \mathrm{W}^{\mathrm{v}} / \mathrm{W}^{\mathrm{v}}: \mathrm{Fas}^{-1-}$ and $+/+$ Fas $^{-1-}$ mice in comparison with those from wild-type $+/+$ :Fas $^{+/+}$mice. Soon after gonadal differentiation at $13 \mathrm{dpc}$, the numbers of oogonia were examined. The formation of primordial follicles and initiation of oocyte growth were examined in ovaries of 2-day old mice. Follicular development and oocyte growth were examined in the ovaries of 14-day old mice. The ovaries from fetal $(13 \mathrm{dpc})$ and neonatal (2-day old) mice were transplanted to immuno deficient mice to study oocyte growth and follicular development under the condition of being isolated from any extraovarian effects of KIT- and Fas-deficiency.

\section{Materials and Methods}

\section{Mice}

Wild-type C57BL/6 $\left(+/+:\right.$ Fas $\left.^{+/+}\right)$and heterozygous KIT-deficient $\left(\mathrm{W}^{\mathrm{V} /+}: \mathrm{Fas}^{+/+}\right)$mice were purchased from SLC Inc., Shizuoka, Japan. A Fas-deficient C57BL/6 background was generated by backcrossing seven times with C57BL/6 mice as previously described by Senju et al. (1995). $\mathrm{W}^{\mathrm{v}} / \mathrm{W}^{\mathrm{v}}: \mathrm{Fas}^{-1-}$ mice were generated by intercrossing heterozygous $\mathrm{W}^{\mathrm{v}} /+: \mathrm{Fas}^{+/+}$mice with Fas-deficient $\left(+/+: \mathrm{Fas}^{-/-}\right)$mice having the same C57BL/6 background as described previously (Sakata et al. 2003). Six- to eight-week old female severe combined immune deficiency (SCID) mice were purchased from CLEA Japan Inc. (Tokyo, Japan). Mice were housed in filter-topped cages in a positive pressure room. The light cycle of the room was set at $12 \mathrm{~h}$ light:12 h darkness. Mice had free access to clean water and balanced feed pellets.

This study was approved by the Institutional Animal Care and Use Committee (Permission number: 16-0801) and carried out according to the Guidelines of Animal Experimentation of Kobe University, Japan.

\section{Genotyping}

The KIT-deficient genotype was distinguished by their coat color. The homozygous KIT-deficient mice were identified by their white coat color, while the heterozygous mice had a black coat with white spots on the neck, back and/or abdomen regions (Fig. 1A). This coat color first appeared at around 2 days after birth. To detect the genotype of the fetuses, small pieces of skins were transplanted under the kidney capsules of SCID mice.
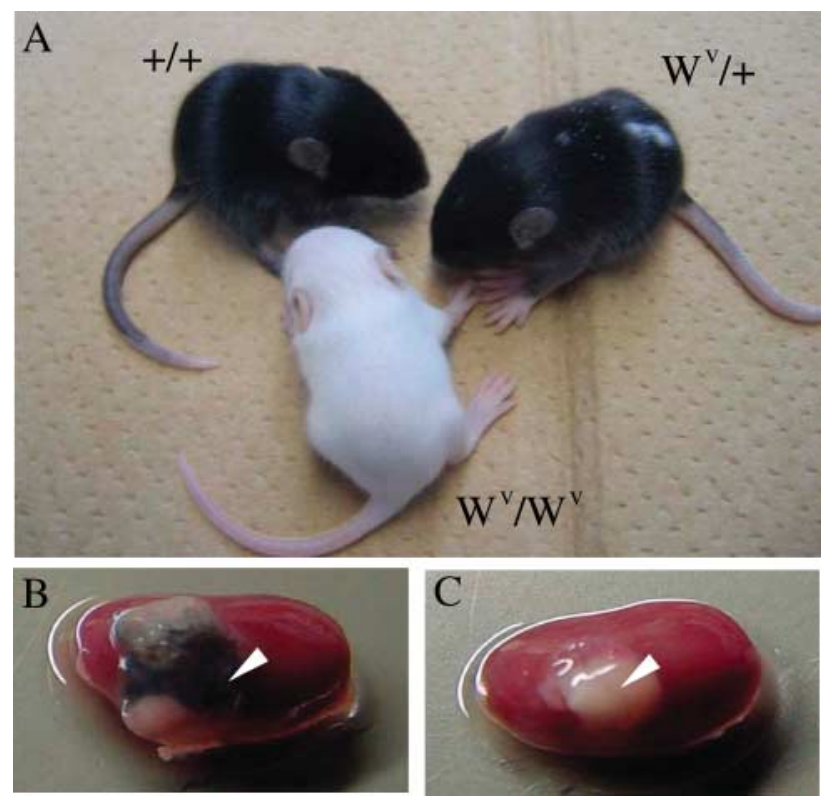

Figure 1 Genotyping of mice for KIT. KIT-deficient mice were identified by their distinguishing coat color (A). The wild-types $(+/+)$ are black. The homozygous KIT-deficient mice $\left(\mathrm{W}^{v} / \mathrm{W}^{v}\right)$ were identified by their white coat color, and the heterozygous mice were black-colored with white spots on the neck, back, and/or abdomen. After transplantation of fetal skins, the color of skins and hairs developed to either black (B) or white (C). Arrow heads indicate transplanted skins. 
After 3 weeks, kidneys were collected and the color of the transplanted skins were examined. White skins corresponded to the homozygous KIT-deficient genotype, $\mathrm{W}^{\mathrm{v}} / \mathrm{W}^{\mathrm{v}}$, and black corresponded to $+/+$ or $\mathrm{W}^{\mathrm{v}} /+$ (Fig. 1B and C).

To identify the Fas-knockout genotype, DNA was isolated from the tail of each mouse using Wizard SV genomic DNA purification system (Promega Corporation) according to manufacturer's protocol. Isolated template DNA was amplified by PCR with two sets of primers and the presence of Fas and neomycin-resistant (Neo) was detected by DNA electrophoresis as described earlier by Senju et al. (1995) with slight change in the primer sets (Fas: 5'-CAGAAGGACCTTGGAAAATCAACC- $3^{\prime}$ and 5'-ATCTCAGCAACTGCAGAGAATAAC3'; Neo: 5'-ATTCGGCTATGACTGGGCACA ACA-3' and 5'-ATGATATTCGGCAAGCAGGCATCG-3'). Wild-type mice were identified as they possessed only Fas without the Neo gene. Heterozygous mice possessed both Fas and $\mathrm{Neo}$ gene expression while only the Neo gene was found in homozygous Fas-knockout mice.

\section{Transplantation}

The sex of fetal gonads at $13 \mathrm{dpc}$ was identified by the testis cords observed in male gonads. Ovaries were collected from $+/+: \mathrm{Fas}^{+/+}\left(\right.$or W $^{\mathrm{v}} /+: \mathrm{Fas}^{+/+} ; n=4$ and $4),+/+:$ Fas $^{-1-}(n=4$ and 4$), \mathrm{W}^{\mathrm{v}} \mathrm{W}^{\mathrm{v}}: \mathrm{Fas}^{+/+}{ }^{\prime}(n=3$ and 3) and $\mathrm{W}^{\mathrm{v}} / \mathrm{W}^{\mathrm{v}}:$ Fas $^{-1-}(n=3$ and 3) mice at $13 \mathrm{dpc}$ and at 2 days respectively. From each mouse, one ovary was transplanted and the other was fixed for histological examination. At 14 days, ovaries were collected from $+/+: \mathrm{Fas}^{+/+}(n=4),+/+: \mathrm{Fas}^{-/-}(n=4), \mathrm{W}^{\mathrm{v}} / \mathrm{W}^{\mathrm{v}}: \mathrm{Fas}^{+/+}$ $(n=4)$ and $\mathrm{W}^{\mathrm{v}} / \mathrm{W}^{\mathrm{v}}: \mathrm{Fas}^{-1-}(n=4)$ mice. From each mouse, one ovary was taken for histological examination. For transplantation, SCID mice were anesthetized by i.p. injection of sodium pentobarbital (Nembutal; Dainippon Pharmaceutical Co. Ltd, Osaka, Japan), and the left kidney was exteriorized. A small hole was torn in the kidney capsule using fine forceps, and one ovary was inserted underneath the capsule of each SCID mouse. The transplantation procedure was performed at room temperature and the mice were kept on a warming plate $\left(37^{\circ} \mathrm{C}\right)$ for $24 \mathrm{~h}$.

Twenty-one and twelve days after transplantations of fetal and neonatal ovaries (corresponding to the ovaries of a 14-day old) respectively, the kidneys containing transplanted ovaries were collected and washed with PBS prior to histological examination.

\section{Histological examinations}

Ovaries and ovarian transplants were fixed in $3 \%$ paraformaldehyde in PBS. They were dehydrated, embedded in methacrylate resin (JB-4; Polyscience Inc., Niles, IL, USA), serially sectioned by $5 \mu \mathrm{m}$, and stained with hematoxylin and eosin. In the fetal ovaries, germ cells were distinguished from somatic cells based on differences in their cellular size (germ cells being much larger than somatic cells) and morphology (germ cells and their nuclei are spherical). The number of germ cells, oocytes, and follicles at various stages were recorded. Follicles were counted in the sections where the oocyte nucleus was seen. To count the number of germ cells, their nuclei were counted in every section. Although the nuclei of germ cells were around $5 \mu \mathrm{m}$, most of the nuclei found in a section were not visible in adjacent sections. However, germ cells and follicles were observed carefully to avoid the double counting in adjacent sections. Follicles were classified according to the number and morphology of granulosa cell layers: primordial follicles with one layer of flattened granulosa cells surrounding the oocyte, primary follicles with a single layer of cuboidal granulosa cells, secondary follicles with two or more layers of granulosa cells but no antrum, and antral follicles having at least an antral cavity with multiple layers of granulosa cells. The diameter of each oocyte (excluding the zona pellucida) was measured by taking the average of two perpendicular measurements of the maximum-diameter section with an ocular micrometer (Nikon, Tokyo, Japan).

\section{Statistical analysis}

Data are presented as the means \pm S.E.M. They were subjected to one-way ANOVA, and the significance of differences among means was determined by Tukey's multiple range test. Differences at $P<0.05$ were considered statistically significant.

\section{Results}

\section{Germ cells and oocytes in ovaries}

At $13 \mathrm{dpc}$, a number of germ cells $(4842 \pm 291(n=4))$ were found in the control $+/+: \mathrm{Fas}^{+/+}\left(\mathrm{or} \mathrm{W}^{\mathrm{V}} /+\mathrm{Fas}^{+/+}\right)$ ovaries (Figs 2 and 4). The number of oocytes decreased to $2363 \pm 126(n=4)$ at 2 days after birth (Figs 3 and 4). Higher numbers of germ cells were found in fetal and postnatal ovaries of $+/+: \mathrm{Fas}^{-/-}\left(\mathrm{or} \mathrm{W}^{\mathrm{v}} /+\mathrm{:Fas}^{-1-}\right)$ mice than in those of $+/+: \mathrm{Fas}^{+/+}\left(\mathrm{or} \mathrm{W}^{\mathrm{V}} /+\mathrm{Fas}^{+/+}\right)$mice (Fig. 4). Ovaries from KIT-deficient mice $\left(\mathrm{W}^{\mathrm{v}} / \mathrm{W}^{\mathrm{v}}: \mathrm{Fas}^{+/+}\right.$ and $\mathrm{W}^{\mathrm{v}} / \mathrm{W}^{\mathrm{v}}: \mathrm{Fas}^{-1-}$ ) were smaller than those from age-matched other genotypes at every stage (Figs 2 and 3). $\mathrm{W}^{\mathrm{v}} \mathrm{W}^{\mathrm{v}}: \mathrm{Fas}^{+/+}$ovaries at $13 \mathrm{dpc}$ contained $1106 \pm 72$ $(n=3)$ germ cells. Their ovaries contained no oocytes at 2 or 14 days of age (Figs 3 and 4 ). On the other hand, a higher number of germ cells $(3843 \pm 108 ; n=3)$ was observed in the $\mathrm{W}^{\mathrm{v}} / \mathrm{W}^{\mathrm{v}}:$ Fas $^{-1-}$ genotypes than in $\mathrm{W}^{\mathrm{v}} / \mathrm{W}^{\mathrm{v}}: \mathrm{Fas}^{+/+}$at 13 dpc. $\mathrm{W}^{\mathrm{v}} / \mathrm{W}^{\mathrm{v}}: \mathrm{Fas}^{-{ }^{-}}$mice contained $528 \pm 91 \quad(n=3)$ oocytes at 2 days of age, but the number decreased to $54 \pm 2(n=4)$ at 14 days. 

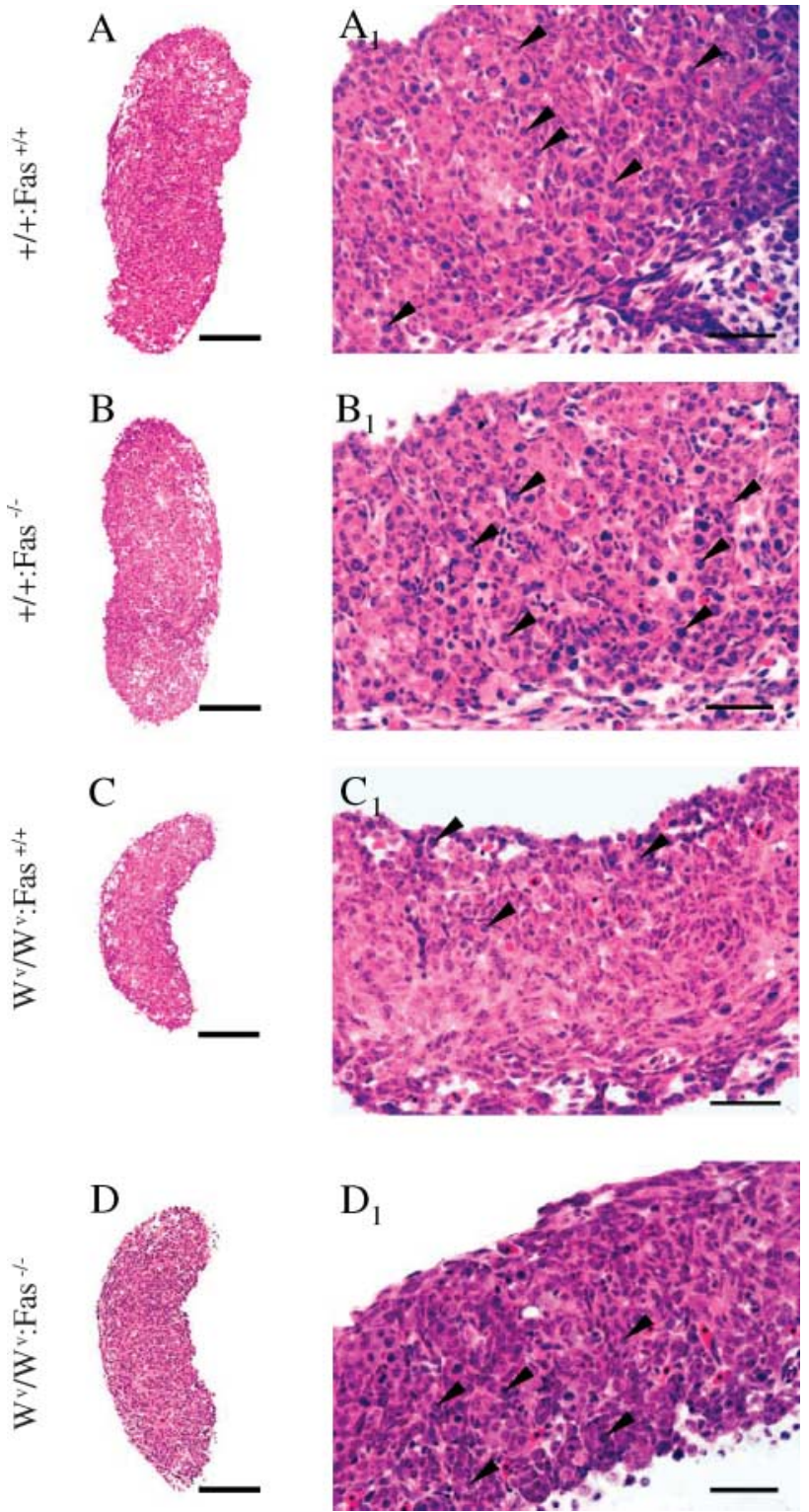

Figure 2 Fetal ovaries at $13 \mathrm{dpc}$ from $+/+\mathrm{Fas}^{+/+}\left(\mathrm{A}\right.$ and $\left.\mathrm{A}_{1}\right),+/+$ :Fas ${ }^{-1-}\left(\mathrm{B}\right.$ and $\left.\mathrm{B}_{1}\right), \mathrm{W}^{\mathrm{v}} / \mathrm{W}^{\mathrm{v}}$ :Fas ${ }^{+/+}\left(\mathrm{C}\right.$ and $\left.\mathrm{C}_{1}\right)$ and $\mathrm{W}^{\mathrm{v}} / \mathrm{W}^{\mathrm{v}}:$ Fas $^{-1-}(\mathrm{D}$ and $\left.D_{1}\right)$ mice. Arrow heads indicate germ cells. Compared with $+/+$ :Fas ${ }^{+++}$, the $\mathrm{W}^{\mathrm{v}} / \mathrm{W}^{\mathrm{v}}$ :Fas ${ }^{+/+}$mouse ovaries were smaller in size and contained fewer germ cells. In $\mathrm{W}^{v} / \mathrm{W}^{v}: \mathrm{Fas}^{-1-}$ mice, increased numbers of germ cells are observed. Scale bars represent $200 \mu \mathrm{m}(\mathrm{A}-\mathrm{D})$ and $60 \mu \mathrm{m}\left(\mathrm{A}_{1}-\mathrm{D}_{1}\right)$.

In 2-day old $+/+: \mathrm{Fas}^{+/+}$and $+/+$Fas $^{-/-}$mice, ovaries contained mostly primordial and a few primary follicles (Fig. 3 and Table 1). In 14-day old, some follicles had developed to the antral stage. In 2-day old $W^{v} /$ $\mathrm{W}^{\mathrm{v}}: \mathrm{Fas}^{-1-}$ mice, few follicles developed to the primary stage, while most follicles remained at the primordial stage. In 14-day old, $15 \pm 1 \% \quad(n=4)$ follicles had developed to the secondary stage, and small proportions $(3 \pm 0 \% ; n=4)$ developed to the antral stage. Table 2 shows the oocyte growth in these mice. In 2-day old $+/+: \mathrm{Fas}^{+/+}$and $+/+: \mathrm{Fas}^{-/-}$mice, ovaries contained
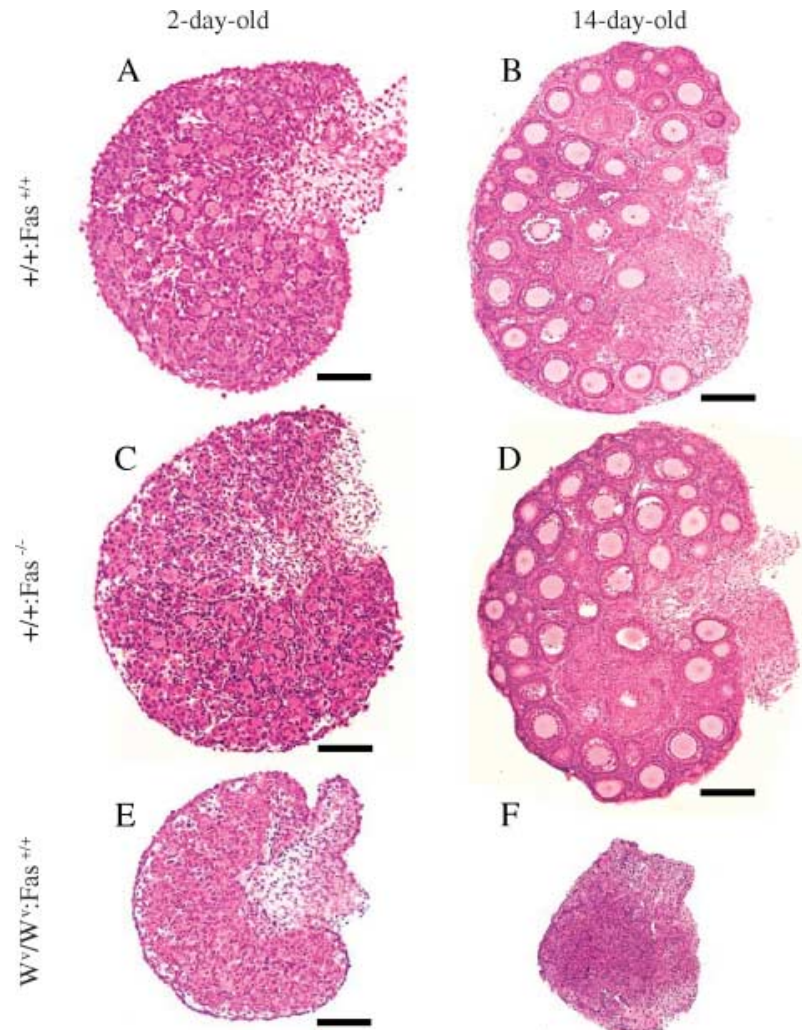

F
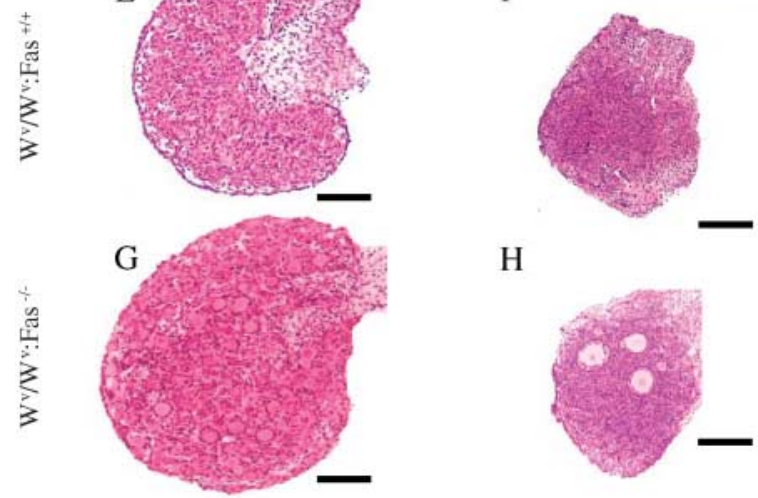

$\mathrm{H}$

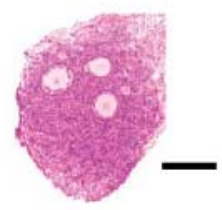

Figure 3 Ovaries from 2- and 14-day old $+/+$ Fas $^{+/+}(\mathrm{A}$ and $\mathrm{B}),+/+$ $:$ Fas $^{-1-}(\mathrm{C}$ and $\mathrm{D}), \mathrm{W}^{\mathrm{v}} / \mathrm{W}^{\mathrm{v}}: \mathrm{Fas}^{+/+}(\mathrm{E}$ and $\mathrm{F})$ and $\mathrm{W}^{\mathrm{v}} \mathrm{W}^{\mathrm{v}} \mathrm{Fas}^{-1-}(\mathrm{G}$ and H) mice. $W^{v} / W^{v}:$ Fas $^{+/+}$mice ovaries contained no oocytes or follicles ( $E$ and $F$ ). In $W^{v} / W^{v}: F^{-1-}$ mice, oocytes survived, and some of them grew accompanied with follicular development $(\mathrm{G}$ and $\mathrm{H})$. Scale bars represent $60 \mu \mathrm{m}(\mathrm{A}, \mathrm{C}, \mathrm{E}$ and $\mathrm{G})$ and $100 \mu \mathrm{m}(\mathrm{B}, \mathrm{D}, \mathrm{F}$ and $\mathrm{H})$.

mainly non-growing oocytes. In 14-day old, some oocytes had grown to more than $50 \mu \mathrm{m}$. Similarly, in $\mathrm{W}^{\mathrm{v}} / \mathrm{W}^{\mathrm{v}} \mathrm{Fas}^{-1-}$ mice, a proportion of oocytes had grown larger than $20 \mu \mathrm{m}$ in diameter at 2 days of age, and growing oocytes of various sizes were observed at 14 days, although the number was significantly lower than those in the other two types of mice.

Thus, this experiment showed that KIT-deficient $\mathrm{W}^{\mathrm{v}} / \mathrm{W}^{\mathrm{v}}: \mathrm{Fas}^{+/+}$mice had no oocytes after birth due to the loss of germ cells in the prenatal stage, while KIT-deficient $\mathrm{W}^{\mathrm{v}} / \mathrm{W}^{\mathrm{v}}: \mathrm{Fas}^{-1-}$ mice maintained some oocytes after birth, and those oocytes grew with follicular development.

\section{Oocyte growth in the transplanted ovaries}

In transplanted fetal and neonatal ovaries, oocytes grew and follicles developed (Figs 5 and 6). Twenty-one days 


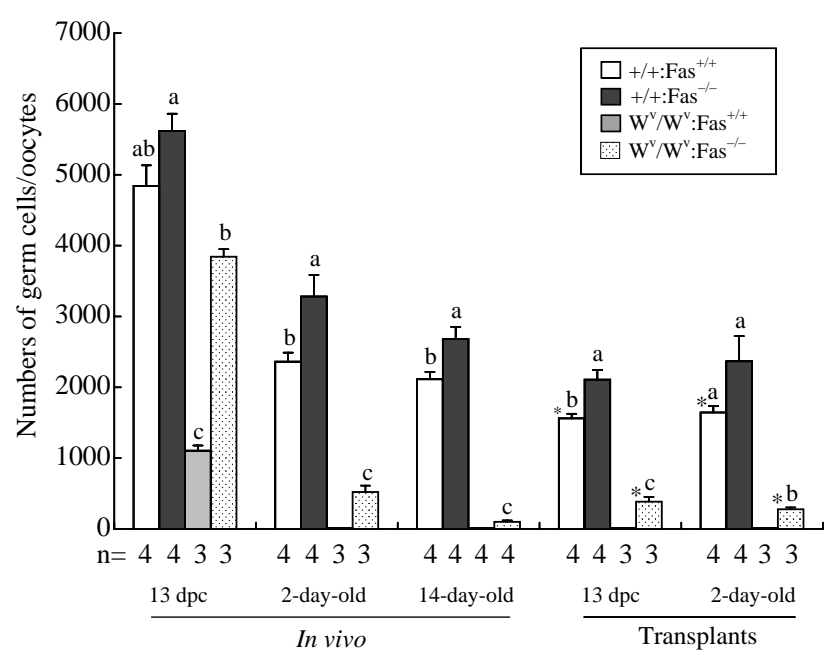

Figure 4 Numbers of germ cells in the ovaries at $13 \mathrm{dpc}$, 2-day old, and 14-day old $+/+:$ Fas $^{+/+},+/+: \mathrm{Fas}^{-1-}, \mathrm{W}^{\mathrm{v}} \mathrm{W}^{\mathrm{v}}: \mathrm{Fas}^{+/+}$and $\mathrm{W}^{v} / \mathrm{W}^{\mathrm{v}}: \mathrm{Fas}^{-1-}$ mice. Numbers of germ cells/oocytes were higher in + $1+:$ Fas $^{-1-}$ mice at all time points than in the same-age $+/+: \mathrm{Fas}^{+/+}$ mice. $\ln \mathrm{W}^{\mathrm{v}} / \mathrm{W}^{\mathrm{v}}:$ Fas $^{+/+}$mice, the number of germ cells at $13 \mathrm{dpc}$ was lower than that of any of the other genotypes. $(\mathrm{a}-\mathrm{c})$ Values with different superscripts in the same age are significantly different $(P<0.05)$. Fetal (13 dpc) and neonatal (2-day old) ovaries from $+/+: \mathrm{Fas}^{+/+}$, and $+/+$ $:$ Fas $^{-1-}, \mathrm{W}^{\mathrm{v}} / \mathrm{W}^{\mathrm{v}}: \mathrm{Fas}^{+/+}$and $\mathrm{W}^{\mathrm{v}} / \mathrm{W}^{\mathrm{v}}: \mathrm{Fas}^{-1-}$ mice were transplanted for 21 and 12 days respectively and the numbers of oocytes were compared with those in the ovaries from 14 -day old mice $\left({ }^{*} P<0.05\right)$.

after transplantation, fetal ovaries from $+/+$ Fas $^{+/+}$and $+/+:$ Fas $^{-/-}$mice contained $1561 \pm 64 \quad(n=4)$ and $2109 \pm 34(n=4)$ oocytes respectively (Fig. 4). Similar numbers of oocytes were obtained at 12 days after transplantation of neonatal ovaries from the same genotypes. No oocytes or germ cells were found after transplantation of fetal and neonatal ovaries from $\mathrm{W}^{\mathrm{v}} /$ $\mathrm{W}^{\mathrm{v}}: \mathrm{Fas}^{+/+}$mice. On the other hand, $384 \pm 66(n=3)$ and $276 \pm 22 \quad(n=3)$ oocytes were obtained after transplantation of fetal and neonatal ovaries from $\mathrm{W}^{\mathrm{v}}$ / $\mathrm{W}^{\mathrm{v}}: \mathrm{Fas}^{-1-}$ mice respectively. The numbers of oocytes in transplants were higher than those in the ovaries of 14-day old in $\mathrm{W}^{\mathrm{v}} / \mathrm{W}^{\mathrm{v}}: \mathrm{Fas}^{-1-}$ mice. The loss of oocytes was significantly reduced in transplanted ovaries.

After transplantation of fetal ovaries from $+/+: \mathrm{Fas}^{+/+}$ and $+/+:$ Fas $^{-1-}$ mice, follicles developed to the antral stage (Fig. 5 and Table 1). Follicular development was also observed in neonatal ovaries after transplantation (Fig. 6). Similarly, after transplantation of fetal and neonatal ovaries from $\mathrm{W}^{\mathrm{v}} / \mathrm{W}^{\mathrm{v}}: \mathrm{Fas}^{-1}$ mice, follicles developed up to the antral stage. The numbers of primary and secondary follicles obtained in the transplanted ovaries were higher than those in the ovaries from 14-day old $\mathrm{W}^{\mathrm{v}} / \mathrm{W}^{\mathrm{v}}$ : $\mathrm{Fas}^{-1-}$ mice (Table 1). After transplantation of fetal ovaries from $+/+\mathrm{Fas}^{+/+}$and $+/+: \mathrm{Fas}^{-/-}$mice, some oocytes grew to more than $50 \mu \mathrm{m}$ in diameter (Table 2). Similarly, growing oocytes were also found in transplanted neonatal ovaries. The numbers of growing oocytes obtained in transplanted ovaries were significantly higher than those in the ovaries of 14-day old $\mathrm{W}^{\mathrm{v}} / \mathrm{W}^{\mathrm{v}}: \mathrm{Fas}^{-1-}$ mice.

These results showed that no germ cells/oocytes survived in the transplanted fetal ovaries from $\mathrm{W}^{\mathrm{v}} / \mathrm{W}^{\mathrm{v}}: \mathrm{Fas}^{+/+}$mice, while oocytes were able to grow with follicular development in the transplanted ovaries from $\mathrm{W}^{\mathrm{v}} \mathrm{W}^{\mathrm{v}}: \mathrm{Fas}^{-1-}$ mice.

Table 1 Follicular development in KIT-deficient $\left(\mathrm{W}^{v} / \mathrm{W}^{v}\right)$ and Fas-knockout $\left(\mathrm{Fas}^{-1-}\right)$ mice.

Number of follicles

\begin{tabular}{|c|c|c|c|c|c|c|c|}
\hline \multirow[b]{2}{*}{ Ovary } & \multirow[b]{2}{*}{ Age } & \multirow[b]{2}{*}{$\begin{array}{l}\text { Duration of } \\
\text { transplantation }\end{array}$} & \multirow[b]{2}{*}{ Follicular stage } & \multicolumn{4}{|c|}{ Number of follicles } \\
\hline & & & & $+/+:$ Fas $^{+/+}$ & $+1+:$ Fas $^{-1-}$ & $\mathrm{W}^{\mathrm{v}} / \mathrm{W}^{\mathrm{v}}: \mathrm{Fas}^{+/+}$ & $\mathrm{W}^{\mathrm{v}} / \mathrm{W}^{\mathrm{v}}: \mathrm{Fas}^{-1-}$ \\
\hline \multirow[t]{10}{*}{ In vivo } & 2-day old & - & & $(n=4)$ & $(n=4)$ & $(n=3)$ & $(n=3)$ \\
\hline & & & Primordial & $2227 \pm 121^{b}$ & $3035 \pm 264^{a}$ & $0 \pm 0$ & $470 \pm 92^{C}$ \\
\hline & & & Primary & $136 \pm 16^{\mathrm{ab}}$ & $246 \pm 54^{\mathrm{a}}$ & $0 \pm 0$ & $58 \pm 16^{\mathrm{b}}$ \\
\hline & & & Secondary & $0 \pm 0$ & $0 \pm 0$ & $0 \pm 0$ & $0 \pm 0$ \\
\hline & & & Antral & $0 \pm 0$ & $0 \pm 0$ & $0 \pm 0$ & $0 \pm 0$ \\
\hline & 14-day old & - & & $(n=4)$ & $(n=4)$ & $(n=4)$ & $(n=4)$ \\
\hline & & & Primordial & $1614 \pm 106^{\mathrm{a}}$ & $1940 \pm 149^{a}$ & $0 \pm 0$ & $33 \pm 5^{b}$ \\
\hline & & & Primary & $309 \pm 22^{\mathrm{a}}$ & $436 \pm 51^{\mathrm{a}}$ & $0 \pm 0$ & $12 \pm 4^{b}$ \\
\hline & & & Secondary & $178 \pm 43^{\mathrm{a}}$ & $293 \pm 64^{\mathrm{a}}$ & $0 \pm 0$ & $10 \pm 1^{b}$ \\
\hline & & & Antral & $13 \pm 2^{\mathrm{a}}$ & $12 \pm 3^{\mathrm{a}}$ & $0 \pm 0$ & $2 \pm 0^{b}$ \\
\hline \multirow[t]{10}{*}{ Transplants } & $13 \mathrm{dpc}$ & 21 days & & $(n=4)$ & $(n=4)$ & $(n=3)$ & $(n=3)$ \\
\hline & & & Primordial & $1128 \pm 74^{\mathrm{b} *}$ & $1655 \pm 170^{a}$ & $0 \pm 0$ & $294 \pm 57^{c *}$ \\
\hline & & & Primary & $272 \pm 14^{\mathrm{a}}$ & $289 \pm 56^{\mathrm{a}}$ & $0 \pm 0$ & $56 \pm 10^{\mathrm{b} *}$ \\
\hline & & & Secondary & $151 \pm 31^{a}$ & $153 \pm 30^{\mathrm{a}}$ & $0 \pm 0$ & $30 \pm 1^{b *}$ \\
\hline & & & Antral & $11 \pm 4^{\mathrm{a}}$ & $12 \pm 2^{\mathrm{a}}$ & $0 \pm 0$ & $5 \pm 1^{a}$ \\
\hline & 2-day old & 12 days & & $(n=4)$ & $(n=4)$ & $(n=3)$ & $(n=3)$ \\
\hline & & & Primordial & $1285 \pm 96^{\mathrm{a}}$ & $1980 \pm 341^{a}$ & $0 \pm 0$ & $198 \pm 21^{b *}$ \\
\hline & & & Primary & $235 \pm 30^{\mathrm{a}}$ & $256 \pm 74^{\mathrm{a}}$ & $0 \pm 0$ & $45 \pm 3^{b *}$ \\
\hline & & & Secondary & $115 \pm 26^{a}$ & $120 \pm 40^{a}$ & $0 \pm 0$ & $34 \pm 5^{\mathrm{b} *}$ \\
\hline & & & Antral & $10 \pm 2^{a}$ & $11 \pm 2^{\mathrm{a}}$ & $0 \pm 0$ & $2 \pm 0^{b}$ \\
\hline
\end{tabular}

\footnotetext{
${ }^{\mathrm{a}-\mathrm{c}}$ Values with different superscripts in the same row are significantly different $(P<0.05) .{ }^{*}$ Values in transplanted ovaries are significantly different from those in the same category in 14-day old mice. ' $n$ ' Indicates the number of ovaries examined. From one mouse, one ovary was taken for histological examination. At $13 \mathrm{dpc}$ and at 2 days, one ovary from each mouse was collected for transplantation. One ovary was transplanted to each SCID mouse.
} 
Table 2 Growth of oocytes in KIT-deficient $\left(\mathrm{W}^{\mathrm{v}} / \mathrm{W}^{\mathrm{v}}\right)$ and Fas-knockout (Fas $\left.{ }^{-1-}\right)$ mice.

\begin{tabular}{|c|c|c|c|c|c|c|c|}
\hline \multirow[b]{2}{*}{ Ovary } & \multirow[b]{2}{*}{ Age } & \multirow[b]{2}{*}{$\begin{array}{l}\text { Duration of } \\
\text { transplantation }\end{array}$} & \multirow[b]{2}{*}{$\begin{array}{l}\text { Diameter of } \\
\text { oocytes }(\mu \mathrm{m})\end{array}$} & \multicolumn{4}{|c|}{ Number of oocytes } \\
\hline & & & & $+/+:$ Fas $^{+/+}$ & $+/+:$Fas $^{-1-}$ & $\mathrm{W}^{\mathrm{v}} \mathrm{M}^{\mathrm{v}}: \mathrm{Fas}^{+/+}$ & $\mathrm{W}^{\mathrm{v}} / \mathrm{W}^{\mathrm{v}}: \mathrm{Fas}^{-1-}$ \\
\hline \multirow[t]{10}{*}{ In vivo } & 2-day old & - & & $(n=4)$ & $(n=4)$ & $(n=3)$ & $(n=3)$ \\
\hline & & & $\leq 20$ & $2295 \pm 140^{b}$ & $3110 \pm 286^{a}$ & $0 \pm 0$ & $465 \pm 59^{c}$ \\
\hline & & & $21-35$ & $69 \pm 16^{\mathrm{b}}$ & $172 \pm 34^{\mathrm{a}}$ & $0 \pm 0$ & $56 \pm 12^{b}$ \\
\hline & & & $36-50$ & $0 \pm 0$ & $0 \pm 0$ & $0 \pm 0$ & $0 \pm 0$ \\
\hline & & & $\geq 51$ & $0 \pm 0$ & $0 \pm 0$ & $0 \pm 0$ & $0 \pm 0$ \\
\hline & 14-day old & - & & $(n=4)$ & $(n=4)$ & $(n=4)$ & $(n=4)$ \\
\hline & & & $\leq 20$ & $1770 \pm 108^{b}$ & $2239 \pm 221^{a}$ & $0 \pm 0$ & $26 \pm 4^{c}$ \\
\hline & & & $21-35$ & $204 \pm 10^{\mathrm{a}}$ & $277 \pm 77^{\mathrm{a}}$ & $0 \pm 0$ & $13 \pm 2^{b}$ \\
\hline & & & $36-50$ & $106 \pm 21^{a}$ & $108 \pm 21^{a}$ & $0 \pm 0$ & $12 \pm 3^{b}$ \\
\hline & & & $\geq 51$ & $35 \pm 8^{a}$ & $58 \pm 18^{\mathrm{a}}$ & $0 \pm 0$ & $4 \pm 1^{b}$ \\
\hline \multirow[t]{10}{*}{ Transplants } & $13 \mathrm{dpc}$ & 21 days & & $(n=4)$ & $(n=4)$ & $(n=3)$ & $(n=3)$ \\
\hline & & & $\leq 20$ & $1261 \pm 77^{b_{*}}$ & $1755 \pm 144^{\mathrm{a} *}$ & $0 \pm 0$ & $239 \pm 46^{\mathrm{C} *}$ \\
\hline & & & $21-35$ & $176 \pm 17^{\mathrm{a}}$ & $207 \pm 19^{a}$ & $0 \pm 0$ & $55 \pm 6^{b *}$ \\
\hline & & & $36-50$ & $92 \pm 12^{\mathrm{a}}$ & $102 \pm 14^{a}$ & $0 \pm 0$ & $56 \pm 3^{a *}$ \\
\hline & & & $\geq 51$ & $33 \pm 7^{a}$ & $45 \pm 11^{\mathrm{a}}$ & $0 \pm 0$ & $35 \pm 15^{\mathrm{a}}$ \\
\hline & 2-day old & 12 days & & $(n=4)$ & $(n=4)$ & $(n=3)$ & $(n=3)$ \\
\hline & & & $\leq 20$ & $1388 \pm 88^{\mathrm{a} *}$ & $2031 \pm 333^{\mathrm{a} *}$ & $0 \pm 0$ & $169 \pm 19^{b} *$ \\
\hline & & & $21-35$ & $153+30^{\mathrm{a}}$ & $204+77^{a}$ & $0+0$ & $56+5^{b *}$ \\
\hline & & & $36-50$ & $73 \pm 12^{\mathrm{a}}$ & $94 \pm 13^{a}$ & $0 \pm 0$ & $40 \pm 8^{a *}$ \\
\hline & & & $\geq 51$ & $31 \pm 10^{a}$ & $38 \pm 13^{a}$ & $0 \pm 0$ & $11 \pm 4^{a}$ \\
\hline
\end{tabular}

${ }^{a-c}$ Values with different superscripts in the same row are significantly different $(P<0.05)$. *Values in transplanted ovaries are significantly different from those in the same category in 14-day old mice. ' $n$ ' Indicates the number of ovaries examined. From one mouse, one ovary was taken for histological examination. At $13 \mathrm{dpc}$ and at 2 days, one ovary from each mouse was collected for transplantation. One ovary was transplanted to each SCID mouse.

\section{Discussion}

Oogenesis begins with the formation of primordial germ cells (PGCs) during the early stage of embryonic development. Proliferating PGCs migrate from the extraembryonic mesoderm to the gonadal ridge. It has been reported that KIT plays a vital role in PGC migration, proliferation and survival (Matsui et al. 1991). At around $11 \mathrm{dpc}, 70 \%$ of the PGCs in the wild-type mice have migrated, while the percentage is as low as 23 in $\mathrm{KL}$ mutant SI/Sl ${ }^{d}$ mice (McCoshen \& McCallion 1975). Defective migration is characteristic of mutations at the W locus (Besmer et al. 1993). Our results also showed a lower number of germ cells at $13 \mathrm{dpc}$ in KIT-deficient $\mathrm{W}^{\mathrm{v}} / \mathrm{W}^{\mathrm{v}}: \mathrm{Fas}^{+/+}$mice than in same-aged wild-types. The decreased number of germ cells caused by KIT-deficiency was ameliorated in $\mathrm{W}^{\mathrm{V}} / \mathrm{W}^{\mathrm{v}}$ : $\mathrm{Fas}^{-1-}$ mice.

The numbers of oocytes found in 2-day old $+/+$ $: \mathrm{Fas}^{-/-}$and $+/+$Fas $^{+/+}$mice were lower than their germ cell populations at $13 \mathrm{dpc}$. The neonatal $+/+$ :Fas $^{-1-}$ mice possessed higher numbers of oocytes than $+/+: \mathrm{Fas}^{+/+}$mice. This might be caused by the lower rate of germ cell/oocyte death induced by Fas (Sakata et al. 2003). KIT-deficient $\mathrm{W}^{\mathrm{v}} / \mathrm{W}^{\mathrm{v}}: \mathrm{Fas}^{+/+}$mouse ovaries contained no oocytes after birth, as reported previously (Russell 1979, Besmer et al. 1993). This suggests that KIT is involved in the survival of germ cells/oocytes in mice. Inhibition of KIT promotes the death of oocytes in vitro (Reynaud et al. 2000). Fas-deficiency rescued the oocytes in neonatal $\mathrm{W}^{\mathrm{v}} /$ $\mathrm{W}^{\mathrm{v}}: \mathrm{Fas}^{-1-}$ mice. However, the numbers of germ cells/ oocytes in fetal and neonatal ovaries were lower in
$\mathrm{W}^{\mathrm{v}} / \mathrm{W}^{\mathrm{v}}: \mathrm{Fas}^{-1-}$ than in $+/+: \mathrm{Fas}^{+/+}$mice. Moreover, a lot of germ cells/oocytes died in $\mathrm{W}^{\mathrm{v}} / \mathrm{W}^{\mathrm{v}}$ : Fas $^{-1-}$ mice, especially in the postnatal period. This is thought to be due to a partial or an incomplete rescue by Fasdeficiency. Some apoptotic factors other than Fas may be involved in the death process of germ cells/oocytes in Fas-knockout mice. It has been reported that a deficiency of p53, a tumor suppressor protein, which is known to cause apoptosis, rescues the germ cells in $W^{v} W^{v}$ mice (Jordan et al. 1999).

$\mathrm{W}^{\mathrm{v}} / \mathrm{W}^{\mathrm{v}}: \mathrm{Fas}^{+1+}$ and $\mathrm{W}^{\mathrm{v}} / \mathrm{W}^{\mathrm{v}}: \mathrm{Fas}^{-1-}$ mice displayed white coat color and poor body conditions. They often died within 2 weeks. To overcome these adverse conditions, their ovaries at the fetal and neonatal stages were transplanted in SCID mice. No oocytes survived in the transplanted ovaries from fetal $\mathrm{W}^{\mathrm{v}} / \mathrm{W}^{\mathrm{v}}: \mathrm{Fas}^{+/+}$mice. This indicates that the survival of germ cells in transplants depends on the genotype of the ovaries. After transplantation of neonatal ovaries from $\mathrm{W}^{\mathrm{v}} / \mathrm{W}^{\mathrm{v}}: \mathrm{Fas}^{+1+}$ mice, oocytes were not generated or supplied from an extragonadal source, as reported by Johnson et al. (2005). They have postulated that new oocytes are generated from germ line stem cells migrating from bone marrow through the blood stream.

The mechanisms concerning the entrance of primordial oocytes into the growth phase remain largely a mystery, with KIT-KL interaction being known to play a pivotal role in this process in rodents. It has been demonstrated that $\mathrm{KL}$ promotes the development of primordial follicles in rodent ovaries in vitro (Packer et al. 1994, Parrott \& Skinner 1999). KL mutant SI/SI ${ }^{t}$ and SIPan/ $\mathrm{SI}^{\mathrm{pan}}$ females are sterile, as their follicular development 

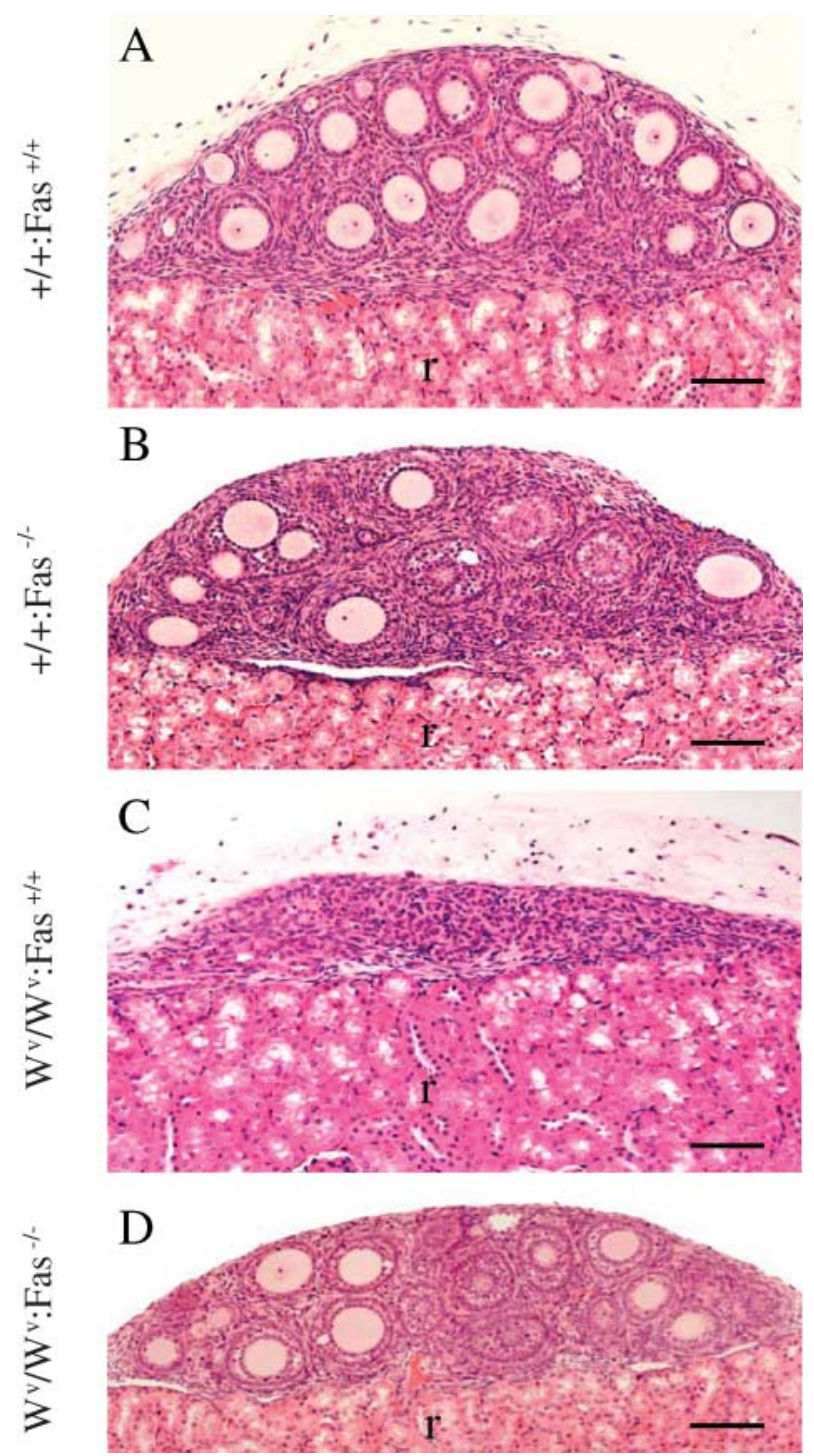

Figure 5 Transplantation of fetal ovaries from $+/+$ Fas $^{+/+},+/+$:Fas $^{-}$ ${ }^{\prime-}, \mathrm{W}^{\mathrm{v}} / \mathrm{W}^{\mathrm{v}}: \mathrm{Fas}^{+/+}$and $\mathrm{W}^{\mathrm{v}} / \mathrm{W}^{\mathrm{v}}: \mathrm{Fas}^{-1-}$ mice at $13 \mathrm{dpc}$ in SCID mice. Twenty-one days after transplantation, follicles developed to the antral stage containing growing oocytes in $(\mathrm{A})+/+\mathrm{Fas}^{+/+}$and $(\mathrm{B})+/+$ :Fas $^{-1-}$ mice. There were no oocytes or follicles in the transplanted ovaries from (C) $\mathrm{W}^{v} / \mathrm{W}^{\mathrm{v}}: \mathrm{Fas}^{+/+}$mice. A proportion of oocytes in the ovaries from $\mathrm{W}^{\mathrm{v}} / \mathrm{W}^{\mathrm{v}}$ : Fas $^{-1-}$ mice survived in transplants and grew accompanied with follicular development (D). ' $r$ ' Indicates the renal tissue of SCID mice. Scale bars represent $60 \mu \mathrm{m}$.

is arrested at the primary stage and oocytes do not grow more than $20 \mu \mathrm{m}$ (Kuroda et al. 1988, Huang et al. 1993). The inhibiting role of KIT has been shown by experiments using its specific antibody, ACK2. The numbers of growing oocytes decreased in ACK2-treated rodent ovaries (Packer et al. 1994, Parrott \& Skinner 1999). Yoshida et al. (1997) injected mice with ACK2 at various times during the first 2 weeks after birth and reported that neutralization of KIT caused disturbances in initial follicle recruitment. However, no direct evidence of the involvement of KIT in oocyte growth
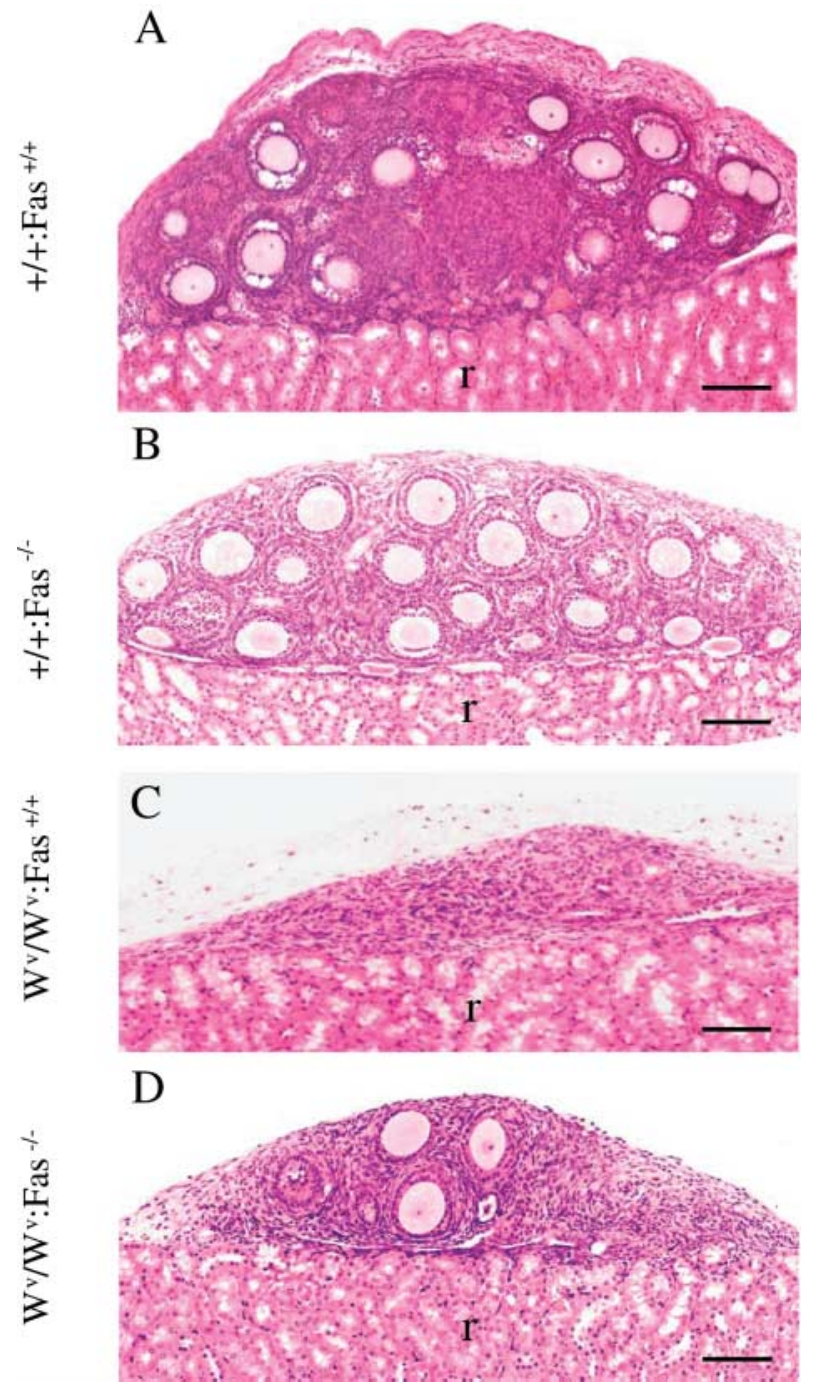

Figure 6 Transplantation of neonatal mouse ovaries to SCID mice. Ovaries were collected from 2-day old $+/+: \mathrm{Fas}^{+/+},+/+\mathrm{Fas}^{-1-}$, $\mathrm{W}^{\mathrm{v}} / \mathrm{W}^{\mathrm{v}}: \mathrm{Fas}^{+/+}$and $\mathrm{W}^{\mathrm{v}} / \mathrm{W}^{\mathrm{v}}$ :Fas $^{-1-}$ mice. Twelve days after transplantation, a proportion of follicles developed to the antral stage containing growing oocytes in $(\mathrm{A})+/+$ : $\mathrm{Fas}^{+/+}$and $(\mathrm{B})+/+: \mathrm{Fas}^{-1-}$ mice. There were no oocytes or follicles in the grafted ovaries of $(C)$ $\mathrm{W}^{\mathrm{v}} / \mathrm{W}^{\mathrm{v}}: \mathrm{Fas}^{+/+}$mice. A proportion of oocytes in the ovaries from $\mathrm{W}^{v} / \mathrm{W}^{\mathrm{v}}: \mathrm{Fas}^{-1-}$ mice survived and grew accompanied with follicular development (D). ' $r$ ' Indicates the renal tissue of SCID mice. Scale bars represent $60 \mu \mathrm{m}$.

has been obtained in KIT mutant mice, because KIT mutation causes severe death of germ cells during the prenatal stage, and therefore, no oocytes survive after birth (Russell 1979, Besmer et al. 1993). The present study shows that oocytes are able to grow with follicular development in KIT-deficient $\mathrm{W}^{\mathrm{v}} / \mathrm{W}^{\mathrm{v}}$ :Fas ${ }^{-1-}$ mice.

Fas might not be associated with oocyte growth or follicular development in mice, because in the $+/+$ :Fas $^{-/-}$genotypes, oocytes grew and follicles developed as in $+/+$ Fas $^{+/+}$. However, Fas-mediated apoptotic signals crosstalk with KIT-mediated survival signals in the mouse gonads. Sakata et al. (2003) detected Fas 
transcripts in the testis of KIT-deficient mice but not in that of wild-types. They have revealed that KIT inhibits Fas-mediated apoptosis through the PI3K (phosphatidylinositol 3-kinase) -AKT (also referred to as protein kinase B) pathway. Blocking of KIT signals by ACK2 causes germ cell degeneration in wild-type, but not in Fasdeficient mice. This indicates that Fas is involved in germ cell degeneration in the absence of KIT signaling. In the absence of both KIT and Fas, the germ cells are rescued. In such a condition, surviving oocytes are able to grow with follicular development. In summary, our results show that oocytes grow and follicles develop without KIT signaling, although KIT might be essential for survival of germ cells/oocytes in mice.

Factors including KL, GDF-9, EGF and leukemia inhibitory factor (LIF) are known to be involved in oocyte growth and follicular development (Eppig 2001, Skinner 2005). It is not clear which factor(s) promotes the processes of oocyte growth and follicular development in a KIT-deficient condition. A recent report suggests that the defects of hematopoietic stem cells induced by KITdeficiency are able to overcome by transgenic expression of erythropoietin (Waskow et al. 2004), whose receptor associates with PI3K (Damen et al. 1993). PI3K (Liu 2006) and AKT (Reddy et al. 2005) are thought to be downstream effectors of KIT, and they mediate oocyte growth. It has not been known whether these intracellular effectors are activated by other cytokines or growth factors to compensate the KIT signaling for oocyte growth and follicular development in a KIT-deficient condition. In this regard, further study is necessary to understand the mechanism involved in oocyte growth and follicular development.

\section{Acknowledgements}

This work was supported in part by the Grant-in-Aid for Scientific Research of the Japan Society for the Promotion of Science to T M and K S, and by the 21 st Century COE program to M M from the Ministry of Education, Culture, Sports, Science and Technology of Japan. The authors declare that there is no conflict of interest that would prejudice the impartiality of this scientific work.

\section{References}

Besmer P, Manova K, Duttlinger R, Huang EJ, Packer A, Gyssler C \& Bachvarova RF 1993 The kit-ligand (steel factor) and its receptor c-kit/W: pleiotropic roles in gametogenesis and melanogenesis. Development (Cambridge, England). Supplement 125-137.

Chabot B, Stephenson DA, Chapman VM, Besmer P \& Bernstein A 1988 The proto-oncogene c-kit encoding a transmembrane tyrosine kinase receptor maps to the mouse W locus. Nature 335 88-89.

Copeland NG, Gilbert DJ, Cho BC, Donovan PJ, Jenkins NA, Cosman D, Anderson D, Lyman SD \& Williams DE 1990 Mast cell growth factor maps near the steel locus on mouse chromosome 10 and is deleted in a number of steel alleles. Cell 63 175-183.
Damen JE, Mui AL, Puil L, Pawson T \& Krystal G 1993 Phosphatidylinositol 3-kinase associates, via its Src homology 2 domains, with the activated erythropoietin receptor. Blood 81 3204-3210.

Driancourt M, Reynaud K, Cortvrindt R \& Smitz J 2000 Roles of KIT and KIT LIGAND in ovarian function. Reproduction 5 143-152.

Eppig J 2001 Oocyte control of ovarian follicular development and function in mammals. Reproduction 122 829-838.

Geissler EN, Ryan MA \& Housman DE 1988 The dominant-white spotting (W) locus of the mouse encodes the c-kit proto-oncogene. Cell 55 185-192.

Guigon CJ \& Magre S 2006 Contribution of germ cells to the differentiation and maturation of the ovary: insights from models of germ cell depletion. Biology of Reproduction 74 450-458.

Huang E, Nocka K, Beier DR, Chu TY, Buck J, Lahm HW, Wellner D, Leder P \& Besmer P 1990 The hematopoietic growth factor KL is encoded by the SI locus and is the ligand of the c-kit receptor, the gene product of the W locus. Cell $63225-233$.

Huang EJ, Manova K, Packer AI, Sanchez S, Bachvarova RF \& Besmer P 1993 The murine steel panda mutation affects kit ligand expression and growth of early ovarian follicles. Developmental Biology 157 100-109.

Johnson J, Bagley J, Skaznik-Wikiel M, Lee HJ, Adams GB, Niikura Y, Tschudy KS, Tilly JC, Cortes ML, Forkert R, Spitzer T, lacomini J, Scadden DT \& Tilly JL 2005 Oocyte generation in adult mammalian ovaries by putative germ cells in bone marrow and peripheral blood. Cell 29 303-315.

Jordan SA, Speed RM \& Jackson IJ 1999 Deficiency of Trp53 rescues the male fertility defects of $\mathrm{Kit}^{\mathrm{W}-\mathrm{v}}$ mice but has no effect on the survival of melanocytes and mast cells. Developmental Biology 215 78-90.

Joyce IM, Pendola FL, Wigglesworth K \& Eppig JJ 1999 Oocyte regulation of kit ligand expression in mouse ovarian follicles. Developmental Biology 214 342-353.

Kuroda H, Terada N, Nakayama H, Matsumoto K \& Kitamura Y 1988 Infertility due to growth arrest of ovarian follicles in SI/Slt mice. Developmental Biology 126 71-79.

Liu K 2006 Stem cell factor (SCF)-kit mediated phosphatidylinositol 3 (PI3) kinase signaling during mammalian oocyte growth and early follicular development. Frontiers in Bioscience 11 126-135.

Manova K, Huang EJ, Angeles M, De Leon V, Sanchez S, Pronovost SM, Besmer P \& Bachvarova RF 1993 The expression pattern of the c-kit ligand in gonads of mice supports a role for the c-kit receptor in oocyte growth and in proliferation of spermatogonia. Developmental Biology 157 85-99.

Matsui Y, Toksoz D, Nishikawa S, Nishikawa S, Williams D, Zsebo K \& Hogan BL 1991 Effect of Steel factor and leukaemia inhibitory factor on murine primordial germ cells in culture. Nature 353 750-752.

McClellan KA, Gosden R \& Taketo T 2003 Continuous loss of oocytes throughout meiotic prophase in the normal mouse ovary. Developmental Biology 258 334-348.

McCoshen JA \& McCallion DJ 1975 A study of the primordial germ cells during their migratory phase in Steel mutant mice. Experientia 31 589-590.

Packer Al, Hsu YC, Besmer P \& Bachvarova RF 1994 The ligand of the c-kit receptor promotes oocyte growth. Developmental Biology 161 194-205.

Parrott JA \& Skinner MK 1999 Kit-ligand/stem cell factor induces primordial follicle development and initiates folliculogenesis. Endocrinology 14 4262-4271.

Reddy P, Shen L, Ren C, Boman K, Lundin E, Ottander U, Lindgren P, Liu YX, Sun QY \& Liu K 2005 Activation of Akt (PKB) and suppression of FKHRL1 in mouse and rat oocytes by stem cell factor during follicular activation and development. Developmental Biology 281 160-170.

Reynaud K \& Driancourt MA 2000 Oocyte attrition. Molecular and Cellular Endocrinology 163 101-108.

Reynaud K, Cortvrindt R, Smitz J \& Driancourt MA 2000 Effects of Kit Ligand and anti-Kit antibody on growth of cultured mouse preantral follicles. Molecular Reproduction and Development 56 483-494. 
Russell ES 1979 Hereditary anemias of the mouse: a review for geneticists. Advances in Genetics 20 357-459.

Sakamaki K, Yoshida H, Nishimura Y, Nishikawa S, Manabe N \& Yonehara S 1997 Involvement of Fas antigen in ovarian follicular atresia and luteolysis. Molecular Reproduction and Development 47 $11-18$.

Sakata S, Sakamaki K, Watanabe K, Nakamura N, Toyokuni S, Nishimune Y, Mori C \& Yonehara S 2003 Involvement of death receptor Fas in germ cell degeneration in gonads of Kit-deficient $\mathrm{W}^{\mathrm{v}} \mathrm{W}^{\mathrm{v}}$ mutant mice. Cell Death and Differentiation 10 676-686.

Senju S, Negishi I, Motoyama N, Wang F, Nakayama KI, Nakayama K, Lucas PJ, Hatakeyama S, Zhang Q, Yonehara S \& Loh DY 1995 Functional significance of the Fas molecule in naive lymphocytes. International Immunology 8 423-431.

Skinner MK 2005 Regulation of primordial follicle assembly and development. Human Reproduction Update 11 461-471.
Waskow C, Terszowski G, Costa C, Gassmann M \& Rodewald H 2004 Rescue of lethal $\mathrm{C}-\mathrm{Kit}^{\mathrm{W} / \mathrm{W}}$ mice by erythropoietin. Blood 104 1688-1695.

Yoshida H, Takakura N, Kataoka H, Kunisada T, Okamura H \& Nishikawa SI 1997 Stepwise requirement of c-kit tyrosine kinase in mouse ovarian follicle development. Developmental Biology 184 122-137.

Zsebo KM, Williams DA, Geissler EN, Broudy VC, Martin FH, Atkins HL, Hsu RY, Birkett NC, Okino KH \& Murdock DC 1990 Stem cell factor is encoded at the SI locus of the mouse and is the ligand for the c-kit tyrosine kinase receptor. Cell 63 213-224.

Received 21 August 2006

First decision 27 September 2006

Accepted 12 October 2006 